\section{Red Cell Exchange Transfusion in Sickle Cell Anaemia Patients at the University College Hospital, Ibadan, Nigeria}

\section{Akingbola $\mathrm{T}^{*}$, Fasola F, Khadijat AS, Alonge T and Chinonso AY}

Departments of Haematology and Trauma \& Orthopaedic Surgery, University College Hospital, Ibadan, Nigeria

*Corresponding author: Akingbola T, Departments of Haematology and Trauma \& Orthopaedic Surgery, University College Hospital, Ibadan, Nigeria, Tel: 2342410088; E-mail: titiakingbola@yahoo.com

Received date: Dec 12, 2017; Accepted date: March 08, 2018; Publish date: March 15, 2018

Copyright: @ 2018 Akingbola T, et al. This is an open-access article distributed under the terms of the Creative Commons Attribution License, which permits unrestricted use, distribution, and reproduction in any medium, provided the original author and source are credited.

\begin{abstract}
Introduction: The prohibitive cost of Haemopoietic Stem Cell Transplant (HSCT) makes many Nigerians with sickle cell anaemia (SCA) dependent on supportive therapies. Red cell exchange (RCE) transfusion (erythrocytaphersis) provides an effective means of improving the oxygen carrying capacity of the patient's red blood cells, reduces blood viscosity, sickled cells and prevents vaso-occlusive and hemolytic complications of SCA. We present three case reports of automated RCE highlighting benefits and potential risks observed following the procedure.
\end{abstract}

Methods: The $\mathrm{COBE}^{\circledR}$ Spectra ${ }^{\mathrm{TM}}$ version 6.1 , which operates by separating blood into its component parts by centrifugation, allowing segmentation by specific gravity, was utilized to conduct automated therapeutic erythrocytapheresis on patients with SCA in this centre. Indications were recurrent priapism, stroke prophylaxis, chronic bone pain crisis, sickle cell nephropathy, pre-surgical requirement, increasing bone pain frequency and chronic transfusion.

Results: Eleven sessions of erythrocytapheresis have been performed on male and female patients at the time of this report. The patient's age range was 19-46 years (mean age: 29.2 years). Indications included recurrent priapism, chronic vasoocclusive crisis, sickle cell nephropathy, pre-surgical requirement, and chronic transfusion recipients. Fifty-five percent had starting haematocrit (Hct) values less than $25 \%$ (mean Hct $21.6 \%$ ). The average post-erythrocytapheresis haematocrit was $28.6 \%$. Post-procedure $\mathrm{HbS}$ levels were less than $40 \%$. Five patients did not experience any adverse effects. Three patients had febrile non-hemolytic transfusion reaction. A patient exhibited symptoms in keeping with acute hypocalcemia and allergic transfusion reaction. Another patient had transfusion-related sepsis.

Conclusion: RCE is an underutilized supportive therapy in SCA. Improving safe blood supply nationwide, subsidizing ancillary investigations and increasing health insurance coverage can make it a preferred option in this setting.

Keywords: Red cell exchange; Sickle cell disease; Haematopoietic stem cell transplant; Therapeutic erythrocytapheresis

\section{Introduction}

Red cell exchange (RCE) transfusion (erythrocytapheresis) provides an effective means of improving the oxygen carrying capacity of the patient's red blood cells, reduces blood viscosity, sickle cells and prevents vaso-occlusive and hemolytic complications of SCA [1]. Red cell exchange in sickle cell disease involves the removal of the patient's red blood cells containing abnormal sickle hemoglobin and replacing them with normal red blood cells carrying normal hemoglobin. The procedure could either be automated or manual. It is used to treat and prevent complications in patients with SCD. This modality of therapeutic apheresis is not widely available in our environment and when available it is grossly underutilized. This is due to a number of reasons. It is beyond the financial reach of the average patient with SCD. Our patients would rather have simple blood transfusion or partial exchange transfusion by manual method, rather than have total red cell exchange using the automated method, to reduce cost. In Nigeria, there are few hospitals where automated RCE has been carried out. We present case reports of 3 patients with homozygous sickle cell disease out of the 11 patients who have undergone automated RCE at $\mathrm{UCH}$, Ibadan. The indications ranged from recurrent priapism, chronic bone pain crisis, sickle cell nephropathy, transfusional iron overload, pre-surgical requirement, increasing bone pain frequency and chronic transfusion. The aim of the report is to highlight series of events in patients undergoing therapeutic erthrocytapharesis with $\mathrm{COBE}^{\circ}$ Spectra ${ }^{\mathrm{m}}$ Version 6.1 in a resources limited country and how the events were handled. In our case series, we report one patient who experienced a life-threatening adverse reaction. This emphasizes the need for the managing team to take necessary steps in preventing transfusion reactions. They should also be alert to warning signs and symptom of these untoward effects in order to handle them early and effectively [2].

\section{Materials and Methods}

The COBE $^{\circ}$ Spectra $^{\text {Tx }}$ Version 6.1 , which operates by separating blood into its component parts by centrifugation, allowing segmentation by specific gravity, was utilized to conduct the first automated therapeutic erythrocytapheresis on patients with SCA in 
this centre. Eleven sessions of erythrocytapheresis have been performed at the time of this report. Indications were recurrent priapism, stroke prophylaxis, chronic bone pain crisis, sickle cell nephropathy, pre-surgical requirement, increasing bone pain frequency and chronic transfusion.

SCD patients with indications for therapeutic RCE and are able to afford the procedure are first educated on the procedure, its benefits and possible risks. After obtaining an informed consent from the patient and/or guardian(s), history, weight and height are taken and physical examination is done. Full blood count (FBC) and peripheral blood film (PBF) review, urinalysis, haemoglobin quantitation, transfusion transmissible infections (TTIs: HIV I and II, anti-HCV, $\mathrm{HBsAg}$ ) testing, electrolyte/urea/creatinine (EUCr) and phosphate, calcium, liver function test and blood grouping are ordered. About 8 to 10 units of group compatible haemoglobin AA packed cell units are crossmatched. The blood units are mandatorily negative for TTIs (HIV I/II, anti HCV, HBsAg, Syphilis) by ELISA screening. A three-way central venous catheter is inserted and the patient is pre-medicated with $1000 \mathrm{mg}$ calcium supplement per oral. His/her vital signs are checked before, during (15 minutes into procedure and every 30 minutes thereafter) and after RCE. Post-apheresis, samples are also sent for FBC, PBF, haemoglobin quantitation and EUCr, calcium and phosphate. Prophylactic antibiotics and anti-malarials are administered and the patient is observed for 30 minutes before discharge.

\section{Results}

The patient's age range was 19-46 years (mean age: 29.2 years). Two patients were female. Six patients $(55 \%)$ had starting haematocrit (Hct) values less than $25 \%$ (mean Hct 21.6\%). The average posterythrocytapheresis haematocrit was $28.6 \%$. Post-procedure $\mathrm{Hb} \mathrm{S}$ levels were less than $40 \%$. Five patients (45\%) did not experience any adverse effects. Three patients (27.3\%) had febrile non-haemolytic transfusion reaction. One patient exhibited symptoms in keeping with acute hypocalcemia and allergic transfusion reaction. Another patient had transfusion-related sepsis.

\section{Case 1}

A 31 year old man diagnosed with SCA at the age of 5 years with recurrent Acute Chest Syndrome, transfusional Iron overload, Systemic Hypertension, Hepatitis B virus infection and End Stage Renal Failure (one year post renal transplant). He was on 3-monthly automated exchange transfusion and medications including antihypertensives, tacrolimus and lamivudine. His steady state haematocrit was $18 \%$. He was not on hydroxyurea therapy. Full blood count (FBC) at presentation showed a presenting haematocrit of $19 \%$, white cell count of $6,470 / \mathrm{mm}^{3}$ (neutrophils $4,270 / \mathrm{mm}^{3}$, lymphocytes $1,230 / \mathrm{mm}^{3}$, monocytes $840 / \mathrm{mm}^{3}$, eosinophil's $130 / \mathrm{mm}^{3}$ ) and platelet count of $481,000 / \mathrm{mm}^{3}$. His serum electrolytes, urea and creatinine (EUCr) analysis revealed normal electrolyte levels [sodium 131 $\mathrm{mmol} / \mathrm{L}$ (normal 130-145), potassium $4.3 \mathrm{mmol} / \mathrm{L}$ (normal 3.5-5.0), chloride $95 \mathrm{mmol} / \mathrm{L}$ (normal 95-110), bicarbonate $23 \mathrm{mmol} / \mathrm{L}$ (normal 20-30)], and corrected serum calcium $8.7 \mathrm{mg} / \mathrm{dl}$ (normal 8.5-10.0). His urea and creatinine values were elevated, $68 \mathrm{mg} / \mathrm{dl}$ (normal 15-45) and $3.7 \mathrm{mg} / \mathrm{dl}$ (normal 0.5-1.5), respectively. Hemoglobin quantitation by high performance liquid chromatography (HPLC) showed HbA was $28.3 \%$, $\mathrm{HbS}$ of $60.6 \%$ and $\mathrm{HbF}$ of $2 \%$. His weight and height were $56 \mathrm{~kg}$ and $175 \mathrm{~cm}$, respectively.
He underwent 181 minutes of erythrocytapheresis in which 2,750 $\mathrm{ml}$ of his blood was exchanged. During the procedure, he complained of circumoral numbness. His blood pressure was also observed to be elevated from $130 / 80 \mathrm{~mm} \mathrm{Hg}$ to $165 / 120 \mathrm{mmHg}$ for which he had intravenous calcium gluconate $10 \mathrm{mg}$ stat and tabs doxazocin $4 \mathrm{mg}$ stat. The rest of the procedure was uneventful. Post-apheresis FBC showed his haematocrit was $25 \%$, white cell count $6,890 / \mathrm{mm}^{3}$ (neutrophils $5,300 / \mathrm{mm}^{3}$, lymphocytes $690 / \mathrm{mm}^{3}$, monocytes $760 / \mathrm{mm}^{3}$, eosinophils $140 / \mathrm{mm}^{3}$ ) and platelets count decreased to $167,000 / \mathrm{mm}^{3}$. His serum EUCr after the procedure revealed potassium had decreased to $3.2 \mathrm{mmol} / \mathrm{L}$, with urea and creatinine levels also reduced to $53 \mathrm{mg} / \mathrm{dl}$ and $2.8 \mathrm{mg} / \mathrm{dl}$, respectively. Repeat haemoglobin quantitation by HPLC showed that his HbA concentration had increased to 59.6\%, while HbS and $\mathrm{HbF}$ decreased to $32.6 \%$ and $0.4 \%$, respectively.

\section{Case 2}

A 46 year old man diagnosed with SCA in childhood who had chronic osteomyelitis of the right tibia following a fracture. $\mathrm{He}$ required erythrocytapheresis in preparation for open reduction and internal fixation of his right tibia on account of non-union. His steady state haematocrit was $24 \%$. He was not on hydroxyurea. At presentation, FBC showed his haematocrit was $25 \%$, white cell count $8,400 / \mathrm{mm}^{3}$ (neutrophils $3,280 / \mathrm{mm}^{3}$, lymphocytes $4,280 / \mathrm{mm}^{3}$, monocytes $840 / \mathrm{mm}^{3}$ ) and platelet count of $463,000 / \mathrm{mm}^{3}$. His serum EUCr analysis was normal with sodium $132 \mathrm{mmol} / \mathrm{L}$, potassium 3.8 $\mathrm{mmol} / \mathrm{L}$, chloride $101 \mathrm{mmol} / \mathrm{L}$, bicarbonate $24 \mathrm{mmol} / \mathrm{L}$, urea $25 \mathrm{mg} / \mathrm{dl}$ and creatinine $0.8 \mathrm{mg} / \mathrm{dl}$. In addition, he had $\mathrm{HbA}$ concentration of $11.3 \%$, $\mathrm{HbS}$ of $82.2 \%$ and $\mathrm{HbF}$ of $2.7 \%$. He was negative for Hepatitis $\mathrm{B}$ virus surface antigen (HBsAg) and antibody to Hepatitis C virus (anti$\mathrm{HCV}$ ) and non-reactive to HIV I and II. His weight and height were 60 $\mathrm{kg}$ and $173 \mathrm{~cm}$, respectively.

He had 3,845 ml of blood was exchanged over 150 minutes without any intra-procedural complaints. Post-apheresis, FBC showed his haematocrit was $30 \%$, white cell count $9,680 / \mathrm{mm}^{3}$ (neutrophils $5,300 / \mathrm{mm}^{3}$, lymphocytes $690 / \mathrm{mm}^{3}$, monocytes $760 / \mathrm{mm}^{3}$, eosinophils $140 / \mathrm{mm}^{3}$ ) and platelets count decreased to $90,000 / \mathrm{mm}^{3}$. Postprocedure serum electrolyte values were as follows: sodium was 129 $\mathrm{mmol} / \mathrm{L}$, potassium $3.6 \mathrm{mmol} / \mathrm{L}$, chloride $97 \mathrm{mmol} / \mathrm{L}$ and bicarbonate $20 \mathrm{mmol} / \mathrm{L}$. Blood urea level reduced to $20 \mathrm{mg} / \mathrm{dl}$ while his creatinine value remained the same. Haemoglobin quantitation by HPLC showed that his $\mathrm{HbA}$ concentration increased to $75.7 \%$, while $\mathrm{HbS}$ and $\mathrm{HbF}$ decreased to $10.5 \%$ and $0.0 \%$, respectively.

\section{Case 3}

A 19 year old lady diagnosed with SCA at infancy. She had a mild clinical course until one year before her presentation when her vasoocclusive crises frequency increased from one per year to seven. She had been transfused twice in the past; the last was 3 years before presentation. Her steady state hematocrit was not known and she was not on hydroxyurea therapy. At presentation, her weight and height were $65 \mathrm{~kg}$ and $163 \mathrm{~cm}$, respectively. Her FBC showed a hematocrit of $25 \%$, white cell count of $11,200 / \mathrm{mm}^{3}$ (neutrophils $6,272 / \mathrm{mm}^{3}$, lymphocytes $4,368 / \mathrm{mm}^{3}$, monocytes $448 / \mathrm{mm}^{3}$, eosinophil's $112 / \mathrm{mm}^{3}$, basophils $112 / \mathrm{mm}^{3}$ ) and platelet count of $503,000 / \mathrm{mm}^{3}$. Her serum EUCr analysis was normal: sodium $138 \mathrm{mmol} / \mathrm{L}$, potassium 4.3 $\mathrm{mmol} / \mathrm{L}$, chloride $108 \mathrm{mmol} / \mathrm{L}$, bicarbonate $22 \mathrm{mmol} / \mathrm{L}$, corrected calcium $9.0 \mathrm{mg} / \mathrm{dl}$; urea and creatinine values $15 \mathrm{mg} / \mathrm{dl}$ and $0.5 \mathrm{mg} / \mathrm{dl}$ respectively. Hemoglobin quantitation by HPLC showed HbA was $6.2 \%, \mathrm{HbS}$ of $84.1 \%, \mathrm{HbA} 24.1 \%$ and $\mathrm{HbF}$ of $5.6 \%$. 
Due to scarcity of ABO group specific blood at the blood bank, 8 units of haemoglobin AA phenotype $\mathrm{O}$ Rh D positive blood (negative for HIV I/II, HBsAg and anti-HCV by ELISA) were sourced from a private blood bank. One hour twenty minutes into the procedure (while on the sixth blood unit) the patient complained of nausea and abdominal pain. This was immediately followed by vomiting and passage of loose stool. She was observed to be suddenly pale, febrile (axillary temperature of $37.8^{\circ} \mathrm{C}$ ), tachycardic (pulse rate was $124 \mathrm{bpm}$ ), hypotensive (systolic blood pressure (BP) was $60 \mathrm{mmHg}$ while the diastolic BP was unrecordable) and tachypneic (respiratory rate of 42 $\mathrm{cpm}$ ). There was no loss of consciousness however she was extremely lethargic. An impression of an Immediate Transfusion Reaction secondary to Transfusion-Related Sepsis, to rule out an Allergic Transfusion Reaction, was made.

Apheresis procedure was immediately discontinued and her identity was re-checked against donor units. She was commenced on supplemental oxygen, $0.9 \%$ saline infusion with monitoring of her urinary output after urethral catheterization. Intravenous (IV) hydrocortisone $200 \mathrm{mg}$ and IV metoclopramide $10 \mathrm{mg}$ stat were administered and her vital signs gradually improved. The patient's samples were sent for full blood count, direct coombs test (DCT), blood culture and urinalysis. The donor bags were also sent to microbiology for blood culture. She was started empirically on parenteral broad spectrum antibiotics (ceftriaxone and metronidazole) and antimalarial. A urine rack was also set up and her hematocrit was monitored daily. Recent onset tender hepatomegaly was observed within 24 hours and confirmed by ultrasound scan. Her liver function test showed hyperbilirubinemia (total and conjugated bilirubin 9.9 $\mathrm{mg} / \mathrm{dl}$ and $4.9 \mathrm{mg} / \mathrm{dl}$, respectively). Urinalysis was normal and the DCT was negative. Blood culture of the donor units grew Klebsiella spp. sensitive to ceftriaxone. Seventy two hours after apheresis, all her symptoms fully resolved and she was discharged home with a hematocrit of $26 \%$ on tabs hydroxyurea, oral antibiotics, haematinics and paludrine (Table 1).

\begin{tabular}{|c|c|c|c|c|c|c|c|c|c|c|c|c|c|}
\hline $\begin{array}{l}\text { Case } \\
\text { No }\end{array}$ & $\begin{array}{l}\text { S.N } \\
\text { o. }\end{array}$ & $\begin{array}{l}\text { Se } \\
x\end{array}$ & $\begin{array}{l}\text { Age } \\
\text { (Yrs) }\end{array}$ & Indication & $\begin{array}{l}\text { Blood } \\
\text { Group }\end{array}$ & Duration & $\begin{array}{l}\text { No. Of } \\
\text { Units } \\
\text { Transfuse } \\
\text { d }\end{array}$ & $\begin{array}{l}\text { Blood } \\
\text { Volume } \\
\text { Exchanged }\end{array}$ & $\begin{array}{l}\text { Adverse } \\
\text { Effects }\end{array}$ & $\begin{array}{l}\text { Initial } \\
\text { Hct }\end{array}$ & $\begin{array}{l}\text { Final } \\
\text { Hct }\end{array}$ & $\begin{array}{l}\text { Initial } \\
\mathrm{HbS}(\%)\end{array}$ & $\begin{array}{l}\text { Final } \\
\text { HbS } \\
(\%)\end{array}$ \\
\hline \multirow{3}{*}{$\begin{array}{l}\text { Case } \\
1\end{array}$} & 1 & M & 31 & Recurrent priapism & $\begin{array}{l}O R h D \\
\text { positive }\end{array}$ & $\begin{array}{l}1 \mathrm{~h} \\
\text { mins }\end{array}$ & 8 & $2,397 \mathrm{mls}$ & None & 28 & 29 & - & - \\
\hline & 2 & M & 29 & Stroke prophylaxis & $\begin{array}{l}\mathrm{O} R \mathrm{Rh} \mathrm{D} \\
\text { positive }\end{array}$ & $\begin{array}{l}2 \mathrm{~h} \\
\text { mins }\end{array}$ & 8 & $2,397 \mathrm{mls}$ & None & 29 & 31 & - & - \\
\hline & $3^{*}$ & M & 31 & $\begin{array}{lcr}\text { Recurrent } & \text { Acute } & \text { Chest } \\
\text { Syndrome, } & \text { End-stage } & \text { renal } \\
\text { disease, Iron-overload } & \end{array}$ & $\begin{array}{l}\text { A Rh } D \\
\text { positive }\end{array}$ & $\begin{array}{l}3 \mathrm{~h} \\
1 \mathrm{mins}\end{array}$ & 8 & $2,750 \mathrm{mls}$ & None & 19 & 25 & 60.6 & 32.6 \\
\hline \multirow{5}{*}{$\begin{array}{l}\text { Case } \\
2\end{array}$} & $4 !$ & M & 23 & Recurrent Acute Chest Syndrome & $\begin{array}{l}\text { A Rh } D \\
\text { positive }\end{array}$ & $\begin{array}{lll}2 & h & 11 \\
\text { mins } & \end{array}$ & 8 & $2,717 \mathrm{mls}$ & FNHTR & 24 & - & - & - \\
\hline & $5 !$ & M & 34 & Chronic bone pain & $\begin{array}{l}\text { A } R h D \\
\text { positive }\end{array}$ & $\begin{array}{l}2 \mathrm{~h} \\
\text { mins }\end{array}$ & 7 & $2,595 \mathrm{mls}$ & FNHTR & 27 & - & - & - \\
\hline & $6 !$ & M & 30 & Recurrent priapism & $\begin{array}{l}\text { A Rh } \mathrm{D} \\
\text { positive }\end{array}$ & $\begin{array}{l}1 \mathrm{~h} \\
\text { mins }\end{array}$ & 8 & $3,220 \mathrm{mls}$ & FNHTR & 22 & - & - & - \\
\hline & $7^{*}$ & $\mathrm{M}$ & 32 & $\begin{array}{lcr}\text { Recurrent } & \text { Acute } & \text { Chest } \\
\text { Syndrome, } & \text { End-stage } & \text { renal } \\
\text { disease, Iron-overload } & \end{array}$ & $\begin{array}{l}\text { A Rh } D \\
\text { positive }\end{array}$ & $\begin{array}{l}2 \mathrm{~h} \\
\text { mins }\end{array}$ & 9 & $3,164 \mathrm{mls}$ & Allergic TR & 18 & 28 & 52.8 & 27.5 \\
\hline & 8 & M & 46 & Pre-surgery & - & $\begin{array}{l}2 \mathrm{~h} \\
\text { mins }\end{array}$ & 8 & $3,845 \mathrm{mls}$ & None & 25 & 30 & 82.2 & 10.5 \\
\hline \multirow{3}{*}{$\begin{array}{l}\text { Case } \\
3\end{array}$} & 9 & $\mathrm{~F}$ & 19 & $\begin{array}{l}\text { Increasing frequency of acute } \\
\text { severe bone pains }\end{array}$ & $\begin{array}{l}\text { O Rh } D \\
\text { positive }\end{array}$ & $\begin{array}{l}1 \mathrm{~h} \\
\text { mins }\end{array}$ & 6 & $2,960 \mathrm{mls}$ & $\begin{array}{l}\text { Transfusion } \\
\text { related } \\
\text { sepsis }\end{array}$ & 25 & 26 & 84.1 & - \\
\hline & 10\# & M & 22 & $\begin{array}{l}\text { Increasing frequency of acute } \\
\text { severe bone pains }\end{array}$ & $\begin{array}{l}\mathrm{ORh} \mathrm{D} \\
\text { positive }\end{array}$ & - & 8 & - & None & 17 & - & - & - \\
\hline & 11 & $\mathrm{~F}$ & 25 & Pre-surgery & $\begin{array}{l}O R h D \\
\text { positive }\end{array}$ & $\begin{array}{l}2 \mathrm{~h} \\
\text { mins }\end{array}$ & 9 & $1,740 \mathrm{mls}$ & None & 22 & 31 & 86.2 & 20 \\
\hline
\end{tabular}

Table 1: Showing summary of Red cell apheresis performed on eleven HbS patients over 2 years.

\section{Discussion}

The beta globin-gene mutation in sickle cell anaemia results in anaemia and repeated bouts of vascular occlusion in affected individuals. The cumulative effect of these vaso-occlusive events is progressive damage to many organs including the kidneys, lungs and brain [3]. Despite much progress in understanding the pathophysiology of SCD and innovations in medical treatments, to date, no therapy is completely effective for the treatment and prevention of complications of SCD [4].

$\mathrm{RCE}$ can be used as acute or chronic transfusion therapy. Acute RCE is used to treat severe or life-threatening complications of $\mathrm{RBC}$ disorders. Acute RCE is useful in acute infarctive stroke, in acute chest 
Citation: $\quad$ Akingbola T, Fasola F, Khadijat AS, Alonge T, Chinonso AY (2018) Red Cell Exchange Transfusion in Sickle Cell Anaemia Patients at the University College Hospital, Ibadan, Nigeria. J Blood Disord Transfus 9: 397. doi:10.4172/2155-9864.1000397

Page 4 of 5

and the multi-organ failure syndromes, and possibly priapism. On the other hand, chronic RCE helps to prevent new or recurrent adverse events, or progression of preexisting organ dysfunction. The American Society for Apheresis (ASFA) classifies indications for therapeutic apheresis into 4 categories on the basis of evidence [5]. The ASFA categories are defined in Table 2 and 3, summarizes the indications for RCE in SCD [4].

\begin{tabular}{|l|l|}
\hline Category & Description \\
\hline I & $\begin{array}{l}\text { Disorders for which apheresis is accepted as first-line therapy, either as a primary stand-alone treatment or in conjunction with other modes of } \\
\text { treatment. }\end{array}$ \\
\hline II & $\begin{array}{l}\text { Disorders for which apheresis is accepted as second-line therapy, either as a stand-alone treatment or in conjunction with other modes of } \\
\text { treatment. }\end{array}$ \\
\hline III & Optimum role of apheresis therapy is not established. Decision making should be individualized. \\
\hline IV & $\begin{array}{l}\text { Disorders in which published evidence demonstrates or suggests apheresis to be ineffective or harmful. Institutional review board approval is } \\
\text { desirable if apheresis treatment is undertaken in these circumstances. }\end{array}$ \\
\hline
\end{tabular}

Table 2: Indications for therapeutic apheresis: ASFA 2010 categories.

\begin{tabular}{|c|c|c|}
\hline \multicolumn{3}{|c|}{ ASFA indication category } \\
\hline & & Non-acute or chronic RCE \\
\hline SCD-related complications & Acute RCE & \\
\hline Acute stroke & 1 & \multirow[b]{5}{*}{-} \\
\hline Acute chest syndrome, severe & II & \\
\hline Multi-organ failure & III & \\
\hline Severe intrahepatic cholestasis & III & \\
\hline Priapism & III & \\
\hline Stroke prophylaxis with prevention of iron overload & & II \\
\hline Vaso-occlusive pain & & III \\
\hline Pre-surgery & & III \\
\hline Pulmonary hypertension & & $\| I^{*}$ \\
\hline End-stage renal disease & \multirow[b]{2}{*}{-} & $\mathrm{III}^{*}$ \\
\hline *No ASFA indication category assigned. & & \\
\hline
\end{tabular}

Table 3: Indications for RBC exchange in SCD

Nigeria has a $2 \%$ birth incidence of sickle cell anaemia and about 150,000 children are born annually with the disorder [6]. University College Hospital (UCH), Ibadan caters to over 2,000 patients with SCD [7]. A cursory examination of in-patient consults at the Department of Hematology, UCH showed that SCD and its complications made up almost $17 \%$ of the total consults. Despite this, only 11 patients could afford erythrocytapheresis in the last two years even though many more would have benefitted.

The 3 patients in our case reports had indications for erythrocytapheresis according to the ASFA guidelines, albeit category II and II indications. The first case in this report had multiple indications (recurrent acute chest syndrome, transfusional iron overload and end stage renal failure), as well as other comorbidities (systemic hypertension and Hepatitis B virus infection). These justified automated erythrocytapheresis as the more appropriate therapeutic approach for the patient. Even though automated RCE has been reported to be 74 times more expensive than the manual method, this patient would not have been considered for RCE by the manual method [8]. This further underscores the advantage of automated over the manual method. The second case presented with post-fracture chronic osteomyelitis of the right tibia. $\mathrm{He}$ underwent erythrocytapheresis as a work up for surgery. In the third case, the indication for the procedure was an increase in the frequency of bone pain crisis.

Erythrocytapheresis is a safe, simple and efficient method of lowering HbS quickly [9]. One procedure of erythrocytapheresis is typically sufficient to treat acute complications of SCD. For acute erythrocytapheresis in SCD, the procedure should aim for a postexchange haematocrit of $\leq 30 \%$ to avoid hyperviscosity. ASFA procedural guidelines also recommends that post-exchange hematocrit levels should not be raised above $27 \%$ [4]. All the cases in this report had final hematocrit levels within these ranges posterythrocytapheresis. Furthermore, to decrease the incidence of postoperative complications such as acute chest syndrome, SCD patients 
who require surgery and $\mathrm{Hb}$ level $>10 \mathrm{~g} / \mathrm{dl}$ would benefit from erythrocytapharesis as it effectively reduces $\mathrm{HbS}$ to $<30 \%$ while maintaining the $\mathrm{Hb}$ levels at $10 \mathrm{~g} / \mathrm{dl}[1,4]$. (Case 2) in this report had chronic osteomyelitis, HbS level of $82.2 \%$ and a hematocrit of $25 \%$ before erythrocytapharesis. FBC showed his hematocrit was $30 \%$ and the $\mathrm{HbS}$ level had decreased to $10.5 \%$ post-apheresis. The procedure was able to achieve the prescribed HbS target in our patients. This is in keeping with studies done by Kim and Swerdlow et al. [1,4].

Despite the usefulness of this procedure, there is a significant limitation in the accessibility, availability and use of therapeutic apheresis in Nigeria [10]. Wun and Hassel [3] stated that patient and family reluctance, inconvenience, difficulty in gaining intravenous access issues, all immunization, red cell availability, infectious disease complications, immune modulation and iron overload are barriers to chronic transfusion therapy. Regardless, therapeutic apheresis can avoid increases in intravascular volume which occur in simple transfusions and is preferred in patients with cardiac or other conditions where fluid overload is a problem [1]. Hilliard et al. [11] evaluated erythrocytapheresis as an alternative to control transfusionrelated iron overload. The authors concluded that apheresis is more expensive than simple transfusion, unless the cost of chelation and organ damage from iron overload are considered.

All standard risks of transfusion therapy are present following erythrocytapheresis. The greater number of units transfused confers a risk of citrate toxicity. This is however easily recognized and treated with calcium (oral or parenteral). Prophylactic calcium gluconate was given to all our patients prior to the procedure. Despite this, one patient (case 1) complained of circumoral numbness intra-procedure and responded well to intravenous calcium gluconate. A patient (case 3) developed an immediate transfusion reaction secondary to transfusion-related sepsis after being transfused with 6 units of blood sourced from a private blood banking facility. This emphasizes the need to maintain quality and standards in blood banking. Maintaining good blood banking system in addition to stringent donor screening and an effective self-deferral system in blood transfusion service reduces the risk of transmission of transfusion transmissible infections such as bacteria transmission. There is also the problem of erythrocyte all immunization which poses serious challenges to safe and effective transfusion [12]. Erythrocytapheresis requires more blood compared with simple transfusion and therefore increases the rate of donor exposure, thus increasing the risks of transfusion transmitted infection and all immunization against RBC antigen $[4,9]$. However, in a study by Hilliard et al. [11], no patient developed an alloantibody or any infectious complications such as Hepatitis B, C or HIV despite the increase in blood utilization and donor exposure.

In conclusion, erythrocytapheresis remains a cost effective, relatively safe, efficient, simple and appropriate therapy in the management of SCD and its complications. Its benefits in preventing or delaying iron-induced organ damage outweigh the risks associated with increased donor exposure and of acquiring blood-borne viral infections from blood transfusion.

\section{References}

1. Swerdlow PS (2006) Red cell exchange in sickle cell disease. Hematology Am Soc Hematol Educ Program 1: 48-53.

2. Danielson CF (2002) The role of red blood cell exchange transfusion in the treatment and prevention of complications of sickle cell disease. Ther Apher 6: 24-31.

3. Wun T, Hassel K (2009) Best practices for transfusion for parents with sickle cell disease. Hematol Rev 1: 22.

4. Kim HC (2014) Red cell exchange: Special focus on sickle cell disease. Hematology Am Soc Hematol Educ Program 1: 450-456.

5. Szczepiorkowski ZM, Winters JL, Bandarenko N, Kim HC, Linenberger ML, et al. (2010) Guidelines on the use of therapeutic apheresis in clinical practice: Evidence-based approach from the apheresis applications committee of the american society for apheresis. J Clin Apher 25: 83-177.

6. http://www.sicklecellfoundation.com/wp-content/uploads/2015/05/NatBurden-SCD.pdf

7. Koehl B, Sommet J, Holvoet L, Abdoul H, Boizeau P, et al. (2016) Comparison of automated erythrocytapheresis versus manual exchange transfusion to treat cerebral macrovasculopathy in sickle cell anaemia. Transfusion 56: 1121-1128.

8. http://nigeriantimes.ng/news/researchers-unveil-new-procedure-forsickle-cell-treatment/

9. Kim HC, Dugan NP, Silber JH, Martin MB, Schwartz E, et al. (1994) Erythrocytapheresis therapy to reduce iron overload in chronically transfused patients with sickle cell disease. Blood 83: 1136-1142.

10. Arogundade FA, Sanusi AA, Oguntola SO, Balogun RA (2014) Benefits and challenges of starting a new therapeutic apharesis service in a resource-constrained setting. J Clin Apher 29: 194-198.

11. Hilliard LM, Williams BF, Lounsbury AE, Howard TH (1998) Erthrocytapharesis limits iron accumulation in chronically transfused sickle cell patients. Am J Hematol 59: 28-35.

12. McGann PT, Hernandez AG, Ware RE (2017) Sickle cell anaemia in SubSaharan Africa: Advancing the clinical paradigm through partnerships and research. Blood 129: 155-161. 